\title{
Hyponatremic Seizure Due to Huge Abdominal Cerebrospinal Fluid Pseudocsyt in a Child with Ventriculoperitoneal Shunt: A Case Report
}

\section{Ventriküloperitoneal Şantlu Bir Çocukta Batındaki Dev Serebrospinal Sıvu Psödokistine Bă̆lı Gelişen Hiponatremik Nöbet: Bir Olgu Sunumu}

Behcet Ilker BUYUKYAVUZ ${ }^{1}$, Levent DUMAN ${ }^{1}$, Tamer KARAASLAN ${ }^{2}$, Aysen TUREDI ${ }^{3}$

${ }^{1}$ Suleyman Demirel University, Faculty of Medicine, Department of Pediatric Surgery, Isparta, Turkey

${ }^{2}$ Suleyman Demirel University, Faculty of Medicine, Department of Neurosurgery, Isparta, Turkey

${ }^{3}$ Dr. Behcet Uz Children Hospital, Department of Pediatrics, Izmir, Turkey

Correspondence address: Levent DUMAN / E-mail: leduman@gmail.com

\begin{abstract}
Placement of ventriculoperitoneal(VP) shunt is a worldwide accepted procedure for treatment of hydrocephalus. This procedure have various intra-abdominal complications, of which pseudocyst formation is a rare one. Common presentations of this complication are abdominal mass, abdominal pain, intestinal obstruction, and shunt dysfunction. In this paper, we report a case of 3 year-old boy with cerebrospinal fluid (CSF) pseudocyst of the VP shunt presenting with hyponatremic seizure. To the best of our knowledge, hyponatremic seizure has not been previously reported as a presentation of abdominal CSF pseudocyst in the literature. Our case has also the largest CSF pseudocyst with respect to body surface area of the child in the literature.
\end{abstract}

KEYWORDS: Children, Hyponatremia, Seizure, Pseudocyst, Ventriculoperitoneal shunt

Öz

Hidrosefali tedavisinde ventriküloperitoneal (VP) şant yerleştirilmesi dünya çapında kabul görmüş bir yöntemdir. Bu yöntemin çeşitli karın içi komplikasyonları vardır. Psödokist oluşumu bu komplikasyonlardan nadir olan biridir. Bu komplikasyon sıklıkla batında kitle, karın ağrısı, barsak tıkanıklığı ve şant fonksiyon bozukluğu ile bulgu verir. Bu yazıda, VP şanta bağlı serebrospinal sıvı psödokisti gelişen ve hiponatremik nöbetle bulgu veren 3 yaşındaki erkek olguyu rapor ettik. Şu andaki bilgilerimize göre, hiponatremik nöbetle bulgu veren batın içi serebrospinal sıvı psödokisti literatürde daha önceden rapor edilmemiştir. Ayrıca olgumuz vücut yüzey alanına göre literatürdeki en büyük psödokiste sahiptir.

ANAHTAR SÖZCÜKLER: Çocuk, Hiponatremi, Nöbet, Psödokist, Ventriküloperitoneal şant

\section{INTRODUCTION}

Cerebrospinal fluid (CSF) pseudocyst is a rare abdominal complication of ventriculoperitoneal (VP) shunts. Although higher rates have been reported (12), this complication develops in less than $1 \%$ of all shunted patients $(2,8)$.

Although the etiology of CSF pseudocyst is not clear, some factors like infections, prior abdominal surgeries, and allergic reactions to silicone or ethylene oxide have been reported to be responsible $(9,11,13)$.

Diagnosis of CSF pseudocyst may be made easily by abdominal ultrasonography (USG) and computerized tomography (CT). In current treatment, pseudocysts are not operated on and they resolve spontaneously after shunt extrusion (6).

In this paper, we report a CSF pseudocyst in a child presenting with a hyponatremic seizure. This is also the largest CSF pseudocyst with respect to body surface area of the child in the literature.

\section{CASE REPORT}

A 3-year-old boy was admitted to our emergency department with complaints of afebrile generalized tonic-clonic seizure, abdominal pain and distention lasting for two days. The history of the patient revealed that the VP shunt had been placed following myelmeningocele closure at 20 days of age.

On physical examination, the patient was somnolent and not oriented. His body temperature was within normal limits. His weight and height were $10 \mathrm{~kg}$ (below the $3^{\text {rd }}$ percentile) and $72 \mathrm{~cm}$ (below the $3^{\text {rd }}$ percentile), respectively. Abdominal examination revealed a giant mass located in the left abdominal quadrants. Laboratory tests showed mild leukocystosis (WBC, 13600/ $\mathrm{mm}^{3}$ ), anemia (hemoglobin, 9.4 $\mathrm{g} / \mathrm{dL}$, hematocrit, 28.8\%), and severe hyponatremia (sodium, $118 \mathrm{mEq} / \mathrm{L}$ ). Other laboratory tests were as follows: potassium, $4.0 \mathrm{mEql} / \mathrm{L}$; chloride, $103 \mathrm{mEq} / \mathrm{L}$; BUN, $12 \mathrm{mg} / \mathrm{dL}$; creatinine, $0.8 \mathrm{mg} / \mathrm{dL}$; uric acid, $3.2 \mathrm{mg} / \mathrm{dL}$, blood osmolality, $254 \mathrm{mOsl} /$ $\mathrm{kg}$, urine specific gravity, 1012; urine osmolality, $420 \mathrm{mOsm} /$ 
$\mathrm{kg}$, and urine sodium, $24 \mathrm{mmol} / \mathrm{L}$. Cranial CT showed bilateral ventricular dilatation (Evans ratio 0.48 ) and periventricular edema (Figure 1). Abdominal CT showed a $15 \times 15 \mathrm{~cm}$ cystic mass located in the left lower and upper abdominal quadrants (Figure 2).

After fluid and sodium replacement, the VP shunt was relocated. The patient was discharged 1 week later following uneventful recovery period and had no seizures during the 1-year follow-up period.

\section{DISCUSSION}

Placement of a VP shunt is a worldwide accepted procedure for treatment of hydrocephalus. Various intra-abdominal complications of this procedure include perforated viscus, inguinal hernia, hydrocele, and abdominal CSF pseudocyst. Common presentations of CSF pseudocyst are abdominal pain, distension, abdominal mass, intestinal obstruction, and shunt dysfunction $(5,7)$. Our patient interestingly presented

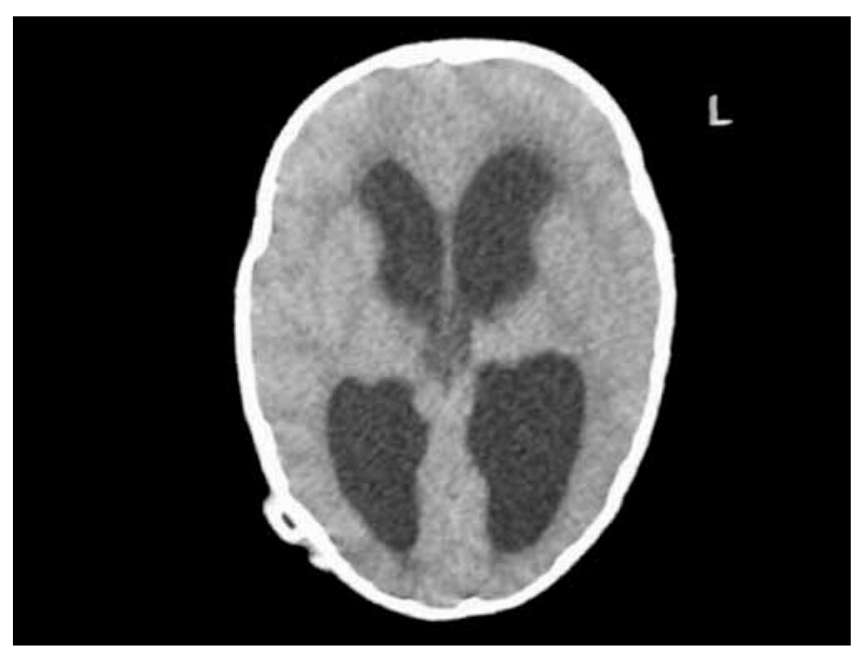

Figure 1: Cranial tomography shows bilateral ventricular dilation and periventricular edema.

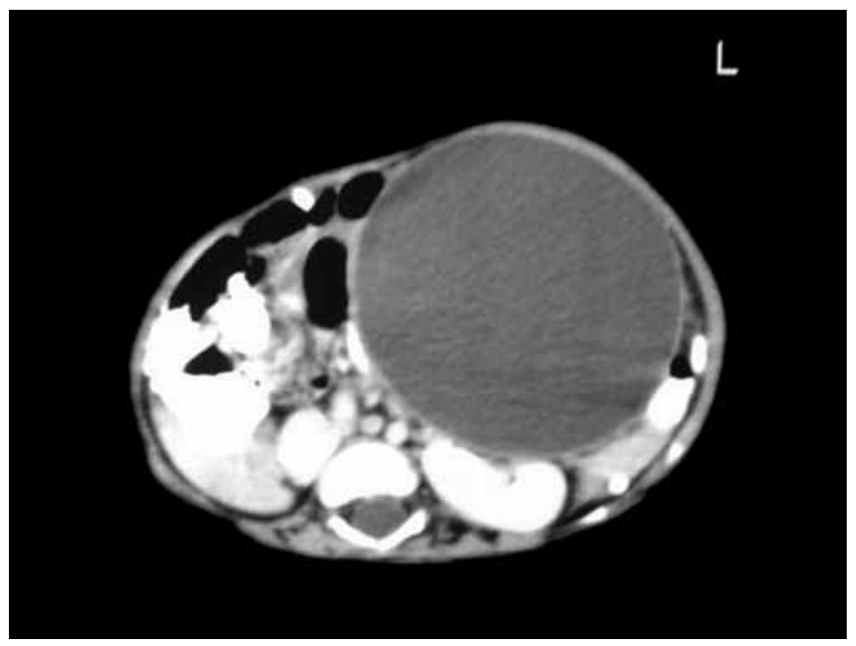

Figure 2: Abdominal tomography shows a giant cystic mass located in the left abdominal quadrants. with hyponatremic seizure in addition to abdominal pain and distention. To the best of our knowledge, this presentation of CSF pseudocyst has not been previously reported in the literature. Although some giant cysts have been reported, our case presented with the largest cyst according to the body surface area of the child $(1,10)$.

Hyponatremia commonly occurs after traumatic brain injury, aneurysmal subarachnoid hemorrhage, transsphenoidal surgery for pituitary tumors, and cranial vault reconstruction for craniosynostosis $(3,4)$. Although hyponatremia due to excessive CSF losses from ventricular drains has been reported, there is no report of hyponatremia due to an abdominal CSF pseudocyst (14).

Syndrome of inappropriate anti-diuretic hormone (SIADH) and cerebral salt wasting (CSW) have been proposed as causes of hyponatremia in patients who have undergone neurosurgery. Hyponatremia is a result of dilution in SIADH, whereas it is the result of primary renal sodium loss in CSW. SIADH is characterized by decreased serum sodium and osmolality with inappropriate urinary concentration, and elevated urine sodium. CSW closely resembles SIADH; but increased hematocrit, and plasma albumin and potassium concentrations, signs of dehydration such as weight loss, poor skin turgor, and low central venous pressure may help to differentiate CSW from $\operatorname{SIADH}(3,4)$. In the light of this information, hyponatremia could not be result of either SIADH or CSW in our case. The relationship between hyponatremia and ventricular drainage has been well demonstrated (14). Thus, the CSF accumulated in the huge pseudocyst may lead to sodium depletion with the same mechanism as ventricular drainage causing CSF loss.

\section{CONCLUSIONS}

A giant CSF pseudocyst may result in hyponatremia due to excessive CSF loss. Therefore, clinicians should be vigilant against hyponatremia which may be result in seizure in cases of huge abdominal CSF pseudocyst. To the best of our knowledge, hyponatremic seizure has not been previously reported as a presentation of abdominal CSF pseudocyst. In this respect, our case is the first one, and has also the largest CSF pseudocyst with respect to the body surface area of the child in the literature.

\section{REFERENCES}

1. Anderson CM, Sorrells DL, Kerby JD: Intraabdominal pseudocysts as a complication of ventriculoperitoneal shunts. J Am Coll Surg 196:297-300, 2003

2. Besson R, Hladky JP, Dhellemmes P, Debeugny P: Peritoneal pseudocyst--ventriculo-peritoneal shunt complications. Eur J Pediatr Surg 5:195-197, 1995

3. Cole CD, Gottfried ON, Liu JK, Couldwell WT: Hyponatremia in the neurosurgical patient: Diagnosis and management. Neurosurg Focus 16:E9, 2004

4. Dooling $E$, Winkelman C: Hyponatremia in the patient with subarachnoid hemorrhage. J Neurosci Nurs 36:130-135, 2004 
5. Ersahin Y, Mutluer S, Tekeli G: Abdominal cerebrospinal fluid pseudocysts. Childs Nerv Syst 12:755-758, 1996

6. Gaskill SJ, Marlin AE: Pseudocysts of the abdomen associated with ventriculoperitoneal shunts: A report of twelve cases and a review of the literature. Pediatr Neurosci 15:23-27, 1989

7. Grosfeld JL, Cooney DR, Smith J, Campbell RL: Intraabdominal complications following ventriculoperitoneal shunt procedures. Pediatrics 54:791-796, 1974

8. Gutierrez FA, Raimondi AJ: Peritoneal cysts: A complication of ventriculoperitoneal shunts. Surgery 79:188-192, 1976

9. Jimenez DF, Keating R, Goodrich JT: Silicone allergy in ventriculoperitoneal shunts. Childs Nerv Syst 10:59-63, 1994

10. Pathi $R$, Sage $M$, Slavotinek J, Hanieh A: Abdominal cerebrospinal fluid pseudocyst. Australas Radiol 48:61-63, 2004
11. Pittman T, Williams D, Rathore M, Knutsen AP, Mueller KR: The role of ethylene oxide allergy in sterile shunt malfunctions. $\mathrm{Br}$ J Neurosurg 8:41-45, 1994

12. Rainov N, Schobess A, Heidecke V, Burkert W: Abdominal CSF pseudocysts in patients with ventriculo-peritoneal shunts. Report of fourteen cases and review of the literature. Acta Neurochir (Wien) 127:73-78, 1994

13. Roitberg BZ, Tomita T, McLone DG: Abdominal cerebrospinal fluid pseudocyst: A complication of ventriculoperitoneal shunt in children. Pediatr Neurosurg 29:267-273, 1998

14. Tobias JD: Cerebrospinal fluid losses through ventricular catheters leading to hyponatremia in two children. South Med J 84:279-280, 1991 